\title{
COFFEE SHOP AS A MEDIA FOR SELF-ACTUALIZATION TODAY'S YOUTH
}

\author{
Salendra \\ (Mr.richendru@gmail.com) \\ (Alumni Jurusan Ilmu Komunikasi Universitas Semarang)
}

\begin{abstract}
Trends go to a coffee shop that is currently self-actualization can be a medium for today's youth. In this study, the author uses Dramaturgy Theory introduced by Erving Goffman 1955 in The Presentation of Self in Everyday Life.

This research methods using qualitative methodology and data collection technique was done by observation, interviews and study by literature. Trends goes to coffee shop by teen nowdays be assumed as teen's activity to follow modern life style and it does to complete needs of self actualization.

It was concluded that the phenomenon of teenage habit to go to the coffee shop is an adolescent self-actualization behaviors performed by following a growing trend. Dramaturgy Theory discusses the two sides of teenage life in self actualize, front stage of a teenager is a person who has wide connections and likes to follow the trend of going to the coffee shop, and the back stage of the teenager is the pupil / student in an educational institution and a child in a family whose primary job is to learn and serve the elderly.
\end{abstract}

Kata Kunci : Youth, Actualization, Coffee Shop

\section{PENDAHULUAN}

Kedai kopi merupakan sebuah tempat yang digunakan oleh masyarakat Indonesia untuk berkumpul dan bersosialisasi bersama orang-orang ataupun tempat untuk melepas lelah setelah seharian bekerja. Kedai kopi umumnya berbentuk sebuah bangunan sederhana yang menjual aneka makanan dan minuman yang secara khusus menawarkan sajian kopi. Kedai kopi mulai beroperasi dari sore hari hingga tengah malam dan biasanya ramai dikunjungi oleh orang-orang dewasa.

Kebiasaan pergi ke kedai kopi ini sudah ada di Indonesia sejak lama dan mengalami perubahan kultur dikarenakan adanya globalisasi dan modernisasi. Starbucks Coffee mengenalkan sebuah kultur kopi modern di Indonesia lewat gerainya yang pertama kali buka di Jakarta pada tahun 2001. Menawarkan sebuah kedai kopi yang modern/ coffee shop dengan aneka sajian kopi ala Amerika, Starbucks Coffee mampu berkembang di Indonesia dan menginspirasi orangorang untuk membuka usaha di bidang yang sama sehingga seiring berjalannya waktu kultur kopi di Indonesia mulai berubah. Perubahan kedai kopi jaman dulu/ tradisional dengan kedai kopi masa kini terlihat dari bentuk bangunan, konsep desain yang modern serta menumenu yang ditawarkan lebih modern dan beraneka ragam. Dilihat dari segi konsumen, kedai kopi dulu merupakan tempat berkumpulnya orang-orang tua atau dewasa, namun sekarang sebaliknya yaitu kedai kopi merupakan tempat berkumpul atau nongkrong remaja-remaja masa kini.

Kedai kopi modern atau bisa disebut dengan Coffee Shop pada umumnya menawarkan sebuah tempat yang bagus dengan perabotan-perabotan modern dan mengutamakan kenyamanan para pelanggan. Dengan berbagai kontent yang ditawarkan seperti desain tempat yang modern, akses wifi gratis, live music dan pelayanan yang bagus, sekarang 
kegiatan ngopi atau nongkrong di kedai kopi merupakan sebagai gaya hidup dan kebutuhan orang-orang masa kini tak terkecuali remaja-remaja.

Perkembangan kedai kopi di Indonesia tidak lepas dari pertumbuhan produksi kopi Indonesia yang merupakan negara penghasil kopi ketiga terbesar di dunia setelah negara Brazil dan Vietnam. Menurut data yang diambil dari situs resmi Direktorat Jenderal Pengolahan dan Pemasaran Hasil Pertanian, Indonesia pada tahun 2010 tercatat melakukan ekspor kopi sebanyak 433,6 ribu ton ke-65 negara tujuan ekspor dengan nilai ekspor US\$ 814,3 juta, angka tersebut belum termasuk jumlah kopi yang diserap oleh pasar lokal atau domestik.

Fenomena menjamurnya kedai kopi di Indonesia ini telah sedikit banyak merubah persepsi masyarakat Indonesia mengenai kedai kopi yang dulunya kedai kopi dianggap sebagai sebuah tempat untuk orang-orang tua berkumpul sekarang telah berubah persepsi bahwa kedai kopi merupakan tempat berkumpul yang populer dan prestise. Selain itu, kepopuleran kedai kopi juga mempengaruhi pola pikir masyarakat bahwa jika ingin mencari tempat nongkrong berarti yang dimaksud adalah pergi ke kedai kopi.

Kebiasan nongkrong di kedai kopi selain dilakukan oleh orang dewasa juga digemari oleh remaja sekolah kelas menengah. Bagi seorang remaja kebutuhan pergi ke kedai kopi berbeda dengan kebutuhan orang-orang dewasa yang pada umumnya pergi ke kedai kopi untuk mengkonsumsi kopi, bertemu rekan bisnis maupun untuk mengerjakan pekerjaan dengan memanfaatkan fasilitas wifi yang ada. Bagi seorang remaja, pergi ke sebuah kedai kopi merupakan sebuah budaya populer tersendiri dimana ketika berada di kedai kopi tersebut selain membeli produknya (makanan dan minuman) tetapi juga membeli nila-nilai prestise yang ditimbulkan dari kepopuleran budaya kedai kopi tersebut sehingga tak jarang remaja masa kini pergi ke kedai kopi hanya untuk memperoleh status sosial yang dianggap tinggi oleh orang lain.

Remaja adalah masa peralihan diantara masa kanak-kanak dan masa dewasa (Darajat, 1990). Dalam masa ini anak mengalami masa pertumbuhan dan masa perkembangan fisiknya maupun perkembangan psikisnya. Mereka bukanlah anak-anak baik dalam bentuk badan ataupun cara berpikir atau bertindak, tetapi bukan pula orang dewasa yang telah matang. Remaja pada umumnya suka mengikuti tren atau budaya populer yang sedang berkembang di masyarakat, hal ini berkaitan dengan kebiasaan remaja masa kini yang suka pergi ke kedai kopi sekedar untuk mengikuti tren yang sedang ada saja, atau dengan kata lain remaja mengaktualisasikan diri dengan mengikuti tren yang sedang ada yaitu nongkrong di kedai kopi.

Kebiasaan remaja pergi ke kedai kopi erat kaitannya dengan kebutuhan aktualisasi diri (self-actualization). Aktualisasi diri menurut Abraham Maslow merupakan proses menjadi diri sendiri serta pemanfaatan potensi/ bakat secara penuh, aktualisasi diri seseorang akan berkembang seiring dengan berjalannya waktu dan tekanan aktualisasi diri akan beralih dari segi fisiologis ke psikologis. Pada fase remaja aktualisasi diri dapat dilakukan dengan mengikuti berbagai macam tren yang sedang ada seperti tren teknologi, musik, fashion dan kebudayaan dll. Dalam penelitian ini Penulis mengkhususkan aktualisasi diri remaja di kedai kopi, bentuk aktualisasi diri remaja di kedai kopi dapat berupa macam-macam tindakan yaitu seperti mengupdate status, berfoto bersama teman-teman yang lalu diunggah ke media sosial. Berikut contoh bentuk aktualisasi diri remaja di kedai kopi : 


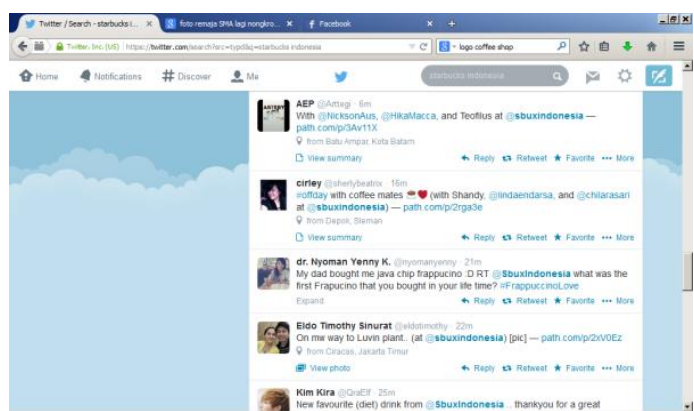

Gambar 1.1 Update Status

Tindakan meng-update status sosial ketika di kedai kopi saat ini sudah banyak dan sering dilakukan oleh remaja masa kini sehingga kita menganggapnya tindakan yang wajar, namun jika diteliti lebih mendalam itu adalah sebuah pengungkapan diri dimana seorang remaja tersebut ingin dilihat dan diapresiasi oleh orang lain.

Selain mengupdate status di media sosial remaja juga suka berfoto bersama yang lalu diunggah ke media sosial seperti foto dibawah ini :

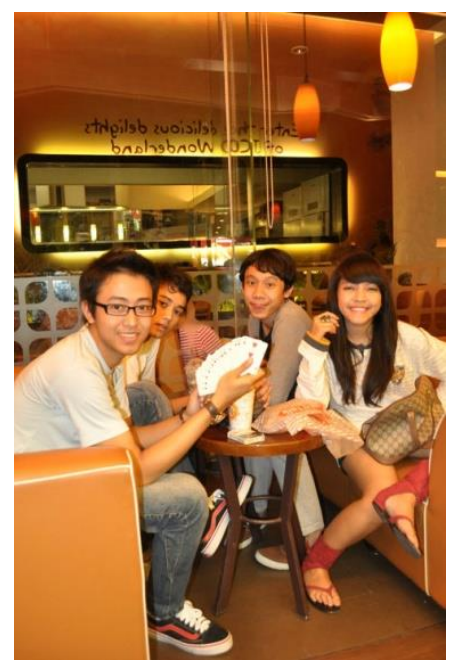

Gambar 1.2 Berfoto Bersama

Selain foto diri yang diunggah ke media sosial, juga banyak remaja beraktualisasi diri dengan mengunggah foto produk yang dibeli dengan menampilkan sebuah brand seperti foto dibawah ini :

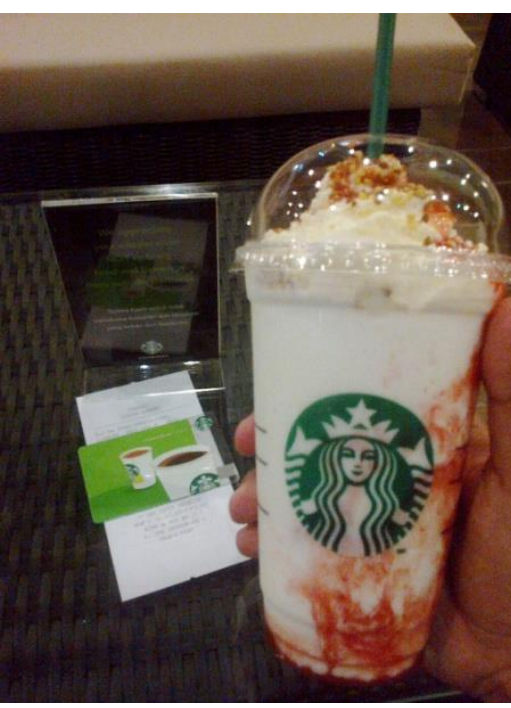

Gambar 1.3 Foto Brand

Perilaku mengunggah foto makanan dan minuman dengan menampilkan brand kedai kopi yang terkenal banyak dilakukan oleh remaja saat ini, dengan mengunggah foto brand tersebut mereka seperti ingin memberitahukan kepada orang banyak bahwa mereka sedang berada di sebuah tren yang sedang ada yaitu pergi ke kedai kopi.

Di dalam penelitian ini Penulis berupaya untuk memahami perilaku remaja dalam beraktualisasi dimana kedai kopi saat ini tampaknya menjadi pilihan mereka untuk beraktualisasi diri. Hal ini menjadi menarik karena sebagai remaja yang masih bersekolah kewajiban utama mereka ialah untuk belajar dan menuntut ilmu, akan tetapi tren atau budaya yang berkembang di masyarakat akan kebiasaan pergi ke kedai kopi mempengaruhi remaja untuk mengikuti tren tersebut bahkan tak jarang mereka pergi ke kedai kopi sampai tengah malam. Hal tersebut tentu menarik untuk diteliti lebih mendalam karena berkaitan dengan beberapa cabang ilmu seperti komunikasi, antropologi budaya dan psikologi.

\subsection{Perumusan Masalah}

Berdasarkan uraian latar belakang masalah di atas, maka yang menjadi pokok permasalahan dalam penulisan 
ini adalah : Bagaimana kedai kopi bisa menjadi media aktualisasi diri bagi remaja masa kini ?

\subsection{Tujuan Penelitian}

Berdasarkan masalah yang diuraikan diatas maka tujuan penelitian ini adalah : Untuk memahami bagaimana kedai kopi bisa menjadi media aktualisasi diri bagi remaja masa kini.

\subsection{Manfaat Penelitian}

Untuk menambah kajian kepustakaan tentang teori Dramaturgi (The Presentational Self) terhadap proses komunikasi remaja masa kini dalam beraktualisasi diri serta untuk mengungkapkan pengalaman subyektif individu dalam menginterpretasikan, memberikan wacana bagi masyarakat mengenai kedai kopi sebagai media aktualisasi remaja masa kini.

\section{TINJAUAN PUSTAKA}

\subsection{The Presentational Self}

The Presentational Self atau Dramaturgi diperkenalkan oleh Erving Goffman pada tahun 1955, teori ini memandang kehidupan sosial merupakan seni pertujukan pentas. Dengan kata lain Goffman menggambarkan peranan orang-orang yang berinteraksi dan berhubungan dengan realitas sosial yang dihadapinya melalui panggung sandiwara dengan menggunakan skrip (jalan cerita) yang telah ditentukan. Goffman juga sering menggunakan perumpamaan pertunjukan teatrikal untuk menjelaskan bagaimana orang-orang berkomunikasi untuk memerankan diri mereka sendiri.

Teori Dramaturgi terdiri dari front stage (panggung depan) dan back Stage (panggung belakang). Front Stage yaitu bagian pertunjukan yang berfungsi mendefinisikan situasi penyaksi pertunjukan. Front stage dibagi menjadi dua bagian, setting yaitu pemandangan fisik yang harus ada jika sang aktor memainkan perannya. Dan front personal yaitu berbagai macam perlengkapan sebagai pembahasa perasaan dari sang aktor. Front personal masih terbagi menjadi dua bagian, yaitu Penampilan yang terdiri dari berbagai jenis barang yang mengenalkan status sosial aktor dan Gaya yang berarti mengenalkan peran macam apa yang dimainkan aktor dalam situasi tertentu. Back stage (panggung belakang) merupakan ruang dimana skenario pertunjukan oleh tim.

Aktualisasi diri, yang menjadi pokok permasalahan di penelitian ini berkaitan dengan teori Dramatugi, dimana orang-orang berperan sebagai aktor dalam berinteraksi dengan orang lain. Remaja, yang tak lain menjadi fokus objek penelitian ini bila dikaitkan dengan Dramatugi, mereka sedang berperan menjadi seorang aktor yang sedang berinteraksi dengan orang lain ataupun lingkungannya dan dengan menggunakan bahasa verbal maupun non verbal berusaha mendapatkan suatu pengakuan akan keberadaannya dengan pergi ke kedai kopi.

\subsection{Konsep Diri}

Menurut Stuart (2002) konsep diri didefinisikan sebagai semua pikiran, keyakinan, dan kepercayaan yang merupakan pengetahuan individu tentang dirinya dan memengaruhi hubungannya dengan orang lain. Konsep diri tidak terbentuk waktu lahir, tetapi dipelajari sebagai hasil pengalaman unik seseorang dalam dirinya sendiri, dengan orang terdekat dan dengan realitas dunia. Berdasarkan pengertian tersebut, konsep diri seseorang akan terbentuk secara terus menerus melalui interaksi sosial dengan orang lain dan dengan lingkungannya.

$$
\text { Menurut Mulyana }
$$

menyatakan konsep diri adalah pandangan individu mengenai siapa diri individu, dan itu bisa diperoleh lewat informasi yang diberikan lewat informasi yang diberikan orang lain pada diri individu. 
Setiap orang tak terkecuali remaja berusaha membentuk konsep diri sepanjang waktu dengan berinteraksi dengan lingkungan maupun masyarakat. Konsep diri ini juga dapat membentuk motif penting untuk berperilaku, seperti dalam Turner (2009) LaRossan dan Reitzes menyatakan bahwa keyakinan, nilai, perasaan, penilaian-penilaian mengenai diri mempengaruhi perilaku, jadi tindakan-tindakan yang dilakukan oleh seorang individu merupakan hasil dari konsep diri individu tersebut. Hal tersebut berkitan dengan remaja-remaja masa kini yang suka pergi ke kedai kopi untuk mengikuti budaya populer, umumnya remaja memiliki konsep diri sebagai seseorang yang memiliki pergaulan yang luas dan memiliki gaya hidup modern. Dengan konsep diri tersebut remaja mulai mengikuti tren nongkrong di kedai kopi sebagai perwujudan perilakunya

\subsection{Kerangka Berpikir}

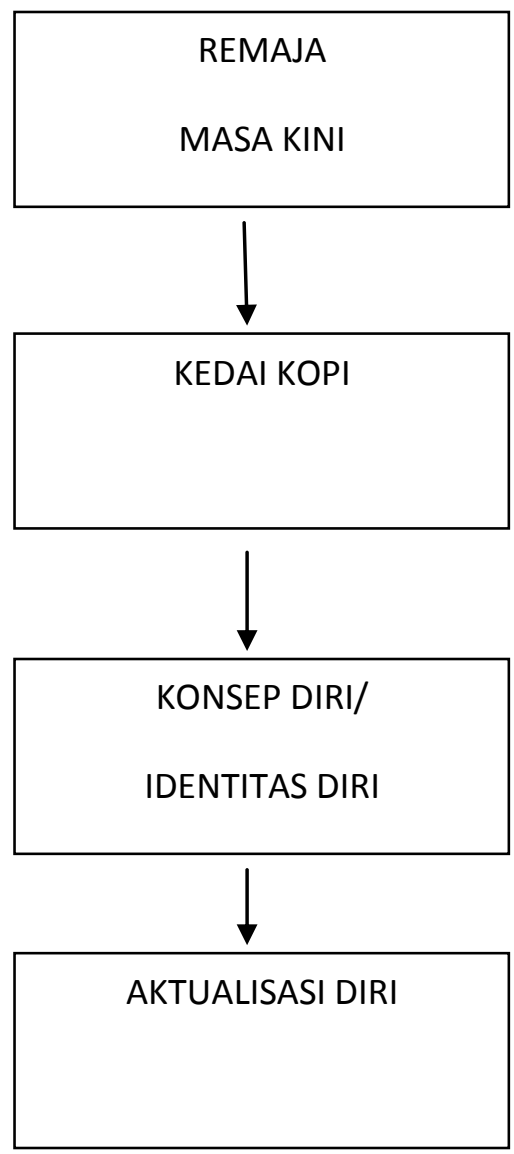

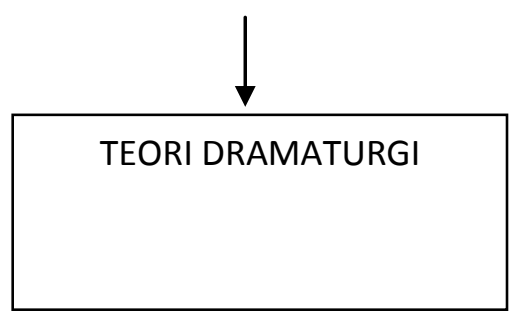

Bagan 2.1 Kerangka Berpikir

\section{HASIL}

\subsection{Temuan di Lapangan}

Penelitian di lapangan telah dilakukan oleh Penulis dengan dengan metode peneletian yang telah ditentukan sebelumnya. Penelitian dengan metode kualitatif ini mendapatkan data dengan cara observasi, wawancara mendalam dan studi pustaka. Dalam pencarian narasumber, Penulis menggunakkan Puspossive Sampling sehingga yang diteliti adalah remaja berusia 15-19 tahun dengan frekuensi pergi ke kedai kopi minimal satu kali dalam sebulan.

Wawancara mendalam telah dilakukan Penulis dengan narasumber dan dalam pengujian validitas data menggunakan metode triangulasi sumber sehingga data yang diperoleh benar-benar valid.

Umumnya remaja-remaja yang diwawancarai penulis sebagai narasumber merupakan pelajar sekolah menengah dan remaja yang akan masuk pendidikan perguruan tinggi. Penulis menemukan bahwa remaja-remaja tersebut tidak begitu mengetahui tentang kopi ataupun kedai kopi, namun mereka suka pergi ke kedai kopi dikarenakan nongkrong di kedai kopi sekarang ini merupakan tren yang sedang populer di kalangan remaja sehingga mereka mengikuti dan menjadi bagian dari tren tersebut.

Penulis menemukan kebutuhan pergi ke sebuah kedai kopi antara orang 
dewasa dengan remaja berbeda, orang dewasa biasa pergi ke kedai kopi untuk memenuhi kebutuhan akan asupan kafein atau untuk bertemu dengan rekan-rekan kerja, namun remajaremaja masa kini pergi ke kedai kopi hanya untuk ngeksis atau untuk bermain-main saja. Seperti pernyataan salah seorang narasumber yang bernama Dara (18th) "kita pergi ke kedai kopi selain buat nongkrong tetapi juga agar terlihat eksis". Pernyataan Dara tersebut tentunya mewakili sebagian besar remaja-remaja masa kini yang pergi ke kedai kopi sebagai media aktualisasi diri saja.

\section{II.PEMBAHASAN}

\subsection{Aktualisasi Diri Remaja Dalam Teori Dramaturgi}

Remaja, di usianya yang masih menginjak belasan tahun gemar untuk mengikuti tren yang sedang populer saat ini. Mengikuti tren yang ada merupakan suatu bentuk aktualisasi diri yang dilakukan para remaja untuk membentuk konsep diri mereka, dan dalam penelitian ini tren yang akan dibahas adalah pergi ke kedai kopi.

Dramaturgi mengasumsikan bahwa kehidupan manusia ibarat sebuah penggung sandiwara atau pementasan. Dalam kehidupan dibagi menjadi 2 stage yaitu front stage (pertunjukan yang sedang dimainkan) dan back stage (tempat mempersiapkan pertunjukan/ setting). Dalam hal ini kehidupan remaja dibagi menjadi dua stage, front stage adalah ketika remaja tersebut berada di kedai kopi dan back stage ketika remaja berada di rumah.

Remaja menampilkan front stage ketika sedang pergi ke kedai kopi, mereka menunjukkan penampilan terbaiknya dengan menggunakan berbagai atribut yang mendukung penampilan mereka seperti : cara berpakaian, gadget yang digunakan, serta produk-produk yang dipesan ketika di sebuah kedai kopi. Tutur bahasa yang digunakan, baik verbal maupun non verbal merupakan bagian dari pertunjukkan yang sedang diperankan oleh remaja tersebut. Dalam memainkan peranannya sebagai seseorang yang mengikuti budaya populer, tentu saja remaja akan berinteraksi dengan lingkungannya melalui berbagai saluran komunikasi. Saluran komunikasi yang biasa digunakan remaja untuk berkomunikasi kepada orang lain yaitu media sosial seperti facebook, twitter, instagram, path dan lain-lain

Hal-hal yang dilakukan remaja dalam mengaktualisasikan dirinya ketika sedang pergi ke kedai kopi adalah melakukan sebuah tindakan yaitu Impression Management. Impression Management atau pengelolaan pesan yang bertujuan untuk memupuk kesan-kesan tertentu dalam situasi tertentu untuk mencapai tujuan. Dalam hal ini tujuan yang ingin dicapai oleh remaja adalah konsep diri mengenai dirinya dari orang lain. Cara yang dilakukan dalam pengelolaan pesan antara lain dengan mengupdate status dan mengupload foto diri mereka/ foto produk ke media sosial seperti gambar ini :

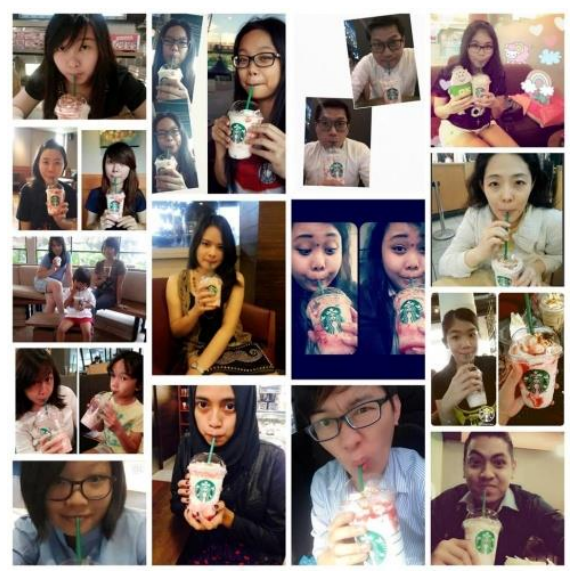

Gambar 3.1 Foto Remaja dan Brand

Hal-hal yang dilakukan dan ditunjukan oleh remaja ketika sedang 
berada di kedai kopi menurut teori Goffman adalah front stage dari sebuah pertunjukan yang sedang dilakukan oleh remaja tersebut, dan hal-hal yang dilakukan merupakan satu kesatuan dari sebuah pesan yang ingin dikelola/ disampaikan kepada khalayaknya yaitu teman-teman mereka. Backstage dari seorang remaja merupakan pelajar sekolah yang sehari-hari tinggal bersama orang tuanya dan belajar merupakan kewajibannya. Saat remaja berada di rumah, mereka akan menunjukan perilaku yang berbeda dengan ketika mereka di kedai kopi. Ketika di rumah biasanya remaja hanya akan menggunakan pakaian sederhana, dan tidak terlalu sering berfoto-foto yang diunggah di media sosial. Saat di rumah juga merupakan sebuah tempat persiapan untuk pertunjukan di panggung pentas yaitu Kedai Kopi.

Penulis menemukan adanya perbedaan sikap atau perilaku ketika seorang remaja berada di rumah dengan ketika berada di sebuah kedai kopi. Rumah, yang menjadi backstage seorang remaja merupakan tempat dimana remaja tersebut menampilkan diri dengan apa adanya. Saat di rumah, remaja biasanya menggunakan pakaian yang seadanya dan menurutnya nyaman untuk dipakai. Remaja tersebut juga tidak menggunakan riasan apa pun ketika di rumah, dan juga tidak memperhatikan tatanan rambut yang merupakan bagian dari style nya. Dalam aktivitas di media sosial saat di rumah, remaja jarang melakukan update status maupun foto sehingga saat di rumah mereka kurang aktif di media sosial.

Umumnya narasumber berasal dari golongan keluarga yang biasa-biasa saja, bahkan beberapa dari mereka berasal dari golongan keluarga yang tidak mampu. Namun ketika remaja tersebut pergi ke sebuah kedai kopi, mereka menunjukkan style terbaiknya dengan menggunakkan pakaian-pakaian model terbaru dan seakan-akan melupakan bahwa mereka berasal dari keluarga yang biasa-biasa saja. Sehingga sangat jelas perbedaan sikap antara di rumah dengan ketika di kedai kopi.

Sikap yang ditunjukan oleh remaja saat di rumah menunjukkan sikap yang sederhana, baik dan menurut kepada orang tua. Tutur bahasa yang digunakan pun masih dalam etika sopan santun yang ada. Remaja menunjukkan kepribadiannya yang sebenarnya ketika berada di rumah. Penulis juga menemukan beberapa remaja yang bukan perokok, namun ketika sedang nongkrong di kedai kopi remaja tersebut merokok agar terlihat keren. Hal ini menjelaskan bagaimana banyak perbedaan kehidupan remaja di lihat dari segi front stage dan back stage. Saat remaja berada dalam front stage, mereka akan menjadi seseorang yang berbeda dengan saat berada di back stage. Di front stage remaja akan

menjadi seseorang yang sangat memperhatikan penampilan, perilaku bahkan sikap-sikap lainnya yang mendukung penampilan mereka agar terlihat menarik layaknya seorang aktor yang sedang pentas di atas panggung.

\subsection{Kedai Kopi Sebagai Media Pembentukan Konsep Diri}

Konsep diri merupakan persepsi individu terhadap dirinya sendiri yang bersifat psikis dan sosial sebagai hasil interaksi dengan orang lain (William D. Brooks dalam Jalaludin Rakhmad, 1985).

Konsep diri merupakan bagian penting dalam kepribadian manusia, konsep diri antara satu individu dengan individu lainnya berbeda-beda dan itu yang membedakan antara manusia yang satu dengan lainnya. Konsep diri ini dibentuk secara terus menerus oleh seorang individu di dalam 
kehidupannya melalui berbagai interaksi dengan diri, orang lain dan lingkungannya.

Seorang remaja, di usianya yang belasan tahun banyak berinteraksi dengan lingkungannya, baik itu lingkungan tempat tinggal maupun lingkungan pergaulannya sehingga mereka secara terus menerus akan melakukan pembentukan konsep diri. Konsep diri seorang remaja juga akan menumbuhkan motif untuk melakukan suatu tindakan.

Menurut observasi Penulis, remaja dalam penelitian ini memiliki konsep diri sebagai individu yang akan memasuki masa dewasa dan ingin mempunyai pergaulan/ pengetahuan yang luas serta selalu ingin mengikuti tren yang ada. Remaja-remaja ini ingin di anggap mempunyai gaya hidup yang berkelas, walaupun beberapa dari mereka berasal dari keluarga yang sederhana. Kepopuleran budaya nongkrong di kedai kopi sekarang ini membuat mereka ingin menjadi bagian dari budaya yang populer tersebut. Mereka menginginkan diri mereka sebagai seorang remaja yang selalu mengikuti tren yang ada, atau bisa disebut tidak ketinggalan jaman.

Seorang remaja yang ingin dianggap sebagai seseorang yang kaya, maka dia akan berperilaku suka berbelanja dan memakai barang-barang yang mewah. Seorang remaja yang ingin dianggap cantik maka dia akan selalu berdandan. Konsep individu mengenai dirinya menimbulkan motif perilaku untuk mewujudkan konsep diri tersebut secara nyata.

Remaja-remaja yang pergi ke kedai kopi umumnya hanya ingin mengikuti tren yang sedang ada. Tren nongkrong di kedai kopi merupakan hal yang populer dan banyak dilakukan oleh remaja saat ini sehingga menurut narasumber nongkrong di kedai kopi merupakan hal yang keren dan prestise. Narasumber ingin membentuk konsep diri bagi dirinya maupun orang lain bahwa dia merupakan seseorang yang eksis dengan nongkrong di kedai kopi. Itu merupakan motif bagi mereka untuk pergi ke kedai kopi bersama temantemannya dan melakukan update status/ foto di media sosial agar orang-orang melihatnya dengan tujuan supaya dianggap orang lain sebagai seseorang yang keren. Dengan melakukan hal-hal tersebut remaja mendapatkan suatu perasaan akan pengakuan dirinya sebagai seseorang yang gaul/ eksis di lingkungan pergaulannya.

\section{KESIMPULAN}

Aktualisasi diri merupakan kebutuhan tertinggi dari seorang individu, kebutuhan aktualisasi diri ini dapat dicapai ketika kebutuhankebutuhan lainnya yang lebih rendah telah terpenuhi seperti kebutuhan fisiologis, rasa aman, kasih sayang dan penghargaan. Aktualisasi diri individu berkembang seiring dengan bertambahnya usia, ketika seseorang semakin besar maka "diri" akan semakin berkembang dan pada saat itu pula tekanan aktualisasi beralih dari segi fisiologis ke psikologis.

Di era globalisasi yang berkembang saat ini telah banyak membawa pengaruh pengaruh luar ke Indonesia, baik dalam kehidupan sosial, politik, hiburan serta kebudayaan. Salah satu pengaruh budaya luar yang menjadi fenomena saat ini adalah budaya nongkrong di kedai kopi. Kebiasaan pergi ke kedai kopi saat ini sudah menjadi tren yang banyak digandrungi oleh remaja masa kini, hal itu terbukti dengan menjamurnya kedai-kedai kopi di berbagai kota di Indonesia tak terkecuali di kota Semarang.

Pada umumnya remaja tidak begitu mengetahui dan menyukai minuman kopi, mereka beranggapan kopi adalah sebuah minuman berwarna 
hitam dan memiliki rasa yang pahit. Namun penulis menemukan banyak remaja-remaja masa kini yang gemar pergi ke kedai kopi khususnya saat malam hari, bahkan narasumber dari penelitian ini mengaku mereka pergi ke kedai kopi setiap malam minggu.

Kepopuleran kedai kopi yang berkembang saat ini menarik minat remaja-remaja untuk pergi ke sana. Di usianya yang sedang berada di masa peralihan menuju dewasa, remaja cenderung mengikuti hal-hal yang sedang menjadi tren sebagai wujud aktualisasi diri mereka. Dengan mengikuti tren yang sedang ada, remaja akan merasa mendapatkan pengakuan sosial atas dirinya sebagai individu yang gaul/ eksis. Berbagai macam kegiatan dilakukan oleh remaja dalam beraktualisasi diri, salah satunya adalah dengan mengikuti budaya nongkrong di kedai kopi. Dengan pergi ke kedai kopi remaja akan mendapatkan suatu perasaan puas

Wujud aktualisasi diri remaja yang dilakukan saat berada di kedai kopi dapat berupa macam-macam hal, salah satunya adalah dengan mengupdate status/ foto di berbagai media sosial mereka sehingga akan diketahui oleh banyak orang. Teori Dramaturgi yang digunakan dalam penelitian ini relevan dengan kondisi pergaulan remaja saat ini, teori ini memandang bahwa sisi kehidupan manusia dibagi menjadi dua yaitu front stage dan back stage. Kedai kopi sebagai media aktualisasi diri remaja masa kini merupakan front stage atau panggung pentas seorang remaja dalam memainkan perannya.

DAFTAR PUSTAKA

Deddy Mulyana. 2000. Ilmu Komunikasi Suatu Pengantar. Bandung : Remaja Rosdakarya.
Jalaluddin Rakhmat. 1985. Psikologi Komunikasi. Bandung : Remaja Karya.

Maslow, Abraham H. 1994. Motivasi dan Kepribadian : Teori Motivasi dengan Pendekatan Hierarki Kebutuhan Manusia. PPM

Stuart, Gail W. Sundeen Sandra J. 2006. Buku Saku Keperawatan Jiwa Edisi 5. Jakarta : EGC

West, Richard. H.Turner, Lynn. 2009. Pengantar Teori Komunikasi : Analisis dan Aplikasi. Jakarta : Salemba Humanika.

Zakiah Daradjat. 1990. Problema Remaja di Indonesia. Jakarta: Bulan Bint 
